\title{
Exploring Parents’ and Teachers’ Views of Primary Pupils' Thinking Skills and Problem Solving Skills
}

\author{
Subadrah Nair, Tang Keow Ngang \\ School of Educational Studies, Universiti Sains Malaysia, Penang, Malaysia \\ Email: \{subadrah, tang\}@usm.my \\ Received April $16^{\text {th }}$, 2011; revised June $11^{\text {th }}$, 2011; accepted July $2^{\text {nd }}, 2011$
}

\begin{abstract}
This article is based on a descriptive study using survey method and focus group interviews. Thinking skills and problem solving skills are vital for pupils in their daily lives and facing their future challenges. Therefore, parents and teachers play an important role in nurturing these skills among pupils. The objective of the study is to explore parents' and teachers' views of pupils' thinking skills and problem solving skills according to locations of the school (urban and rural). This study also explores parents' and teachers' suggestions to enhance pupils' thinking skills and problem solving skills. The sample consists of 302 parents of the pupils and 104 teachers who are teaching Year 4, Year 5 and Year 6. The quantitative data for the research was collected using questionnaires which were developed by the researchers. Each set of questionnaire consists of 23 items. While the qualitative data was collected through the focus group interview method among parents and teachers to get their suggestions on how to enhance pupils' thinking skills and problem solving skills. The findings show that the urban parents' views of children's thinking skills and problem solving skills is significantly higher than those from the rural. The results also indicate that there is no significant difference between the urban school teachers' and the rural school teachers' views of pupils' thinking skills and problem solving skills. Findings from the focus group interviews show that most parents engage their children in hands on activities at home to enhance their thinking skills and problem solving skills. On the other hand, teachers encourage active participation of pupils in co-curricular activities to enhance pupils’ thinking skills and problem solving skills.
\end{abstract}

Keywords: Thinking Skills; Problem Solving Skills; Teachers’ and Parents’ Views; Urban and Rural National Schools

\section{Introduction}

Thinking skills and problem solving skills are incorporated in the teaching and learning activities of all the subjects taught in primary and secondary schools in Malaysia. Thinking skills and problem solving skills are given emphasis in the Malaysian school curriculum to equip pupils to face challenges in their daily lives and in their future. It is vital to nurture thinking skills and problem solving skills among pupils so that they are able to think critically and creatively in solving problems. Parents and teachers play a very important role in nurturing these skills among pupils (Ahmed, 2009). In schools, teachers infuse thinking skills and problem solving skills through various subjects taught in the school curriculum. Effective teachers engage pupils in various learning activities which encourage the pupil to think and solve problems (Beyer, 1987). Parents too play an important role in educating children and they remain the primary educators of their children (The Learning Community 2011-TLC). Parents can also foster critical thinking at home by asking questions that lack a single correct answer, and ask them casually (Duke Gifted Letter, 2006). Meanwhile parents play a supportive role in helping the children to acquire these skills. Parents as the role models for children, guide them to be better thinkers and enhance children's thinking skills and problem solving skills.

According to Mumford, Mobley, Uhlman, Reiter-Palmon, and Doares (1991), there are two types of problem solving such as creative problem solving and general problem solving. Crea- tive problem solving is ill defined and ambiguous, have multiple appropriate and acceptable solutions. On the other hand general problem solving is well defined and have one correct solution and they do not allow creativity. Beyer (1987) describe that thinking skills can be taught through six stages such as introduction of the skill, gradual practice, individual application, transfer and elaboration, guided practice in new situation and autonomous use. Guilford (1967), categorized problem solving as creative and creative production is generated when solving problems. Problem solving used in this study is creative problem solving as such de Bono's CoRT thinking tools are appropriate to gauge pupils' creative thinking skills and problem solving skills.

In this study, pupils thinking skills and problem solving skills refers to the ability of pupils to generate ideas related to tasks given to them. The items given in the questionnaires for parents and teachers are similar and are related to de Bono's CoRT thinking tools such as Plus Minus Interesting (PMI), Consider All Factors (CAF), RULES, Consequences and Sequences ( $C$ \& S), Aims Goals and Objective (AGO), PLANNING, First Important Priority (FIP), Alternatives Possibilities and Choices (APC), DECISIONS and Other People Views (OPV). For each item parents and teachers are required to gauge the ability of pupils, to generate creative ideas according to five scales such as very high, high, average, low and very low.

\section{Objectives of the Study}

The objective of this study is to investigate whether there is 
significant difference in parents' and teachers' views of primary pupils' thinking skills and problem solving skills according to the location of the schools (urban and rural). Besides that, this study also aims to obtain parents' and teachers' suggestions on how to enhance pupils' thinking skills and problem solving skills.

Two null hypotheses were tested at the 0.05 significance level and two research questions were answered in this study. The null hypotheses and the research questions are as follows:

Ho1: There is no significant difference in the parents' views of children's thinking skills and problem solving skills according to location.

Ho2: There is no significant difference in the teachers' views of pupils' thinking skills and problem solving skills according to location.

Research Question 1: What are the parents' suggestions to enhance children's thinking skills and problem solving skills?

Research Question 2: What are the teachers' suggestions to enhance pupils' thinking skills and problem solving skills?

\section{Literature Review}

\section{Thinking Skills and Problem Solving Skills}

Study on thinking skills and problem solving skills has been great concern among researchers. Dewey (1938) is the pioneer in developing thinking skills among pupils through reflective teaching. Some researchers like Bloom (1956), Spache (1978), Barrett (1972), Smith (1969), encouraged pupils to think by using questions from the lowest order to the higher orders. De Bono (1991) proposed CoRT thinking tools to enhance pupils' thinking skills and problem solving skills. Pupils thinking skills and creativity can also be enhanced by using mind mapping (Buzan, 1986) and concept mapping (Novak \& Gowin, 1984). Gardner (1984) explored the theory of multiple intelligences in enhancing thinking skills and problem solving skills. The seven intelligences proposed to by Gardner are linguistics, mathematical, spatial, bodily-kinesthetic, musical, interpersonal and interpersonal. Amabile (1983), Mumford (2001) and Sternberg (1988) define creativity with respect to novelty (unique) and appropriateness.

Nurturing thinking skills and problem solving skills among pupils is vital in this $21^{\text {st }}$ century to enable them to face the various challenges in their daily lives and in solving problems at their work places. According to Campbell and Dickinson (1996), there are three types of thinking skills, namely problem solving skills in real situations, skills to generate ideas to solve new problems and the ability to do or offer useful service in certain cultures. Tillery (2006) pointed out that the problem solving skill is an effort to find solutions to difficult situation where one needs advanced thinking skills in problem solving. Thinking skills also help a person to choose the ideal strategy to solve the problem that is being faced.

Schafersman (1991) stressed that teaching critical thinking skills in the sciences or in any other discipline is to improve the thinking skills of the student. Clement and Lochhead (1980) pointed out that "We should be teaching students how to think. Instead we are teaching them what to think." (Lochhead, 1980 in Schafersman, 1991: p. 1).

There are two contradictory schools of thought among researchers on how to teach thinking skills to pupils. Clarke (1990) explained that thinking skills should be infused in the teaching and learning of every subject in school. Beyer (1991), Swartz and Parks (1994) and Meyers (1986) also suggested that thinking skills should be incorporated in the school curriculum. On the other hand, de Bono (1991) argued that thinking skills should be taught separately and should not be infused in subjects taught in schools.

In the Malaysian school curriculum, thinking skills and problem solving skills are emphasized at both the primary and secondary school levels. Starting from the year 1980, thinking skills have been infused into subjects in the Primary School Integrated Curriculum (KBSR) as an added value. These skills are also continually infused into every subject at the secondary school level to enhance pupils' thinking skills and problem solving skills. Primary school teachers and secondary school teachers are also trained to employ various strategies to help pupils develop their thinking skills and problem solving skills.

Parents and teachers play an important role in developing pupils' thinking skills and problem solving skills. In Malaysia, research related to parents' and teachers' roles in enhancing pupils' thinking skills and problem solving skills is limited. As such, it is necessary to investigate the parents' and teachers' views of primary school pupils' thinking skills and problem solving skills and identify their suggestions to enhance those skills among pupils.

\section{De Bono's CoRT Thinking Tools}

De Bono (1991) in his discussion has elaborated the methods of teaching thinking skills to students, such as the 'osmosis' method (teachers imparting acquired thinking skills to students), logic regulation, having discussions and using CoRT thinking tools. Besides that, de Bono also suggested "thinking hats" as a method to enhance thinking skills.

De Bono's thinking tools in CoRT1 Breath is to broaden ones perception in various situations. The ten CoRT thinking tools by de Bono are mainly Plus Minus and Interesting (PMI), Consider All Factors (CAF), Rules, Consequences and Sequences (C \& S), Aims Goals and Objectives (AGO), Planning, First Important Priority (FIP), Alternatives Possibilities and Choices (APC), Decision and Other People's Views (OPV). The questionnaires prepared by the researchers to gauge parents' and teachers' views of pupils' thinking skills are based on de Bono's CoRT thinking tools.

\section{Methodology}

\section{Samples}

In this study, the researchers used purposive sampling, only one best class of Year 4, 5 and 6 from each school is used in the study. This is because some rural schools has only two classes for each year and some pupils from the second class are slow readers. As such researchers only choose the best class from the urban and rural schools.

In addition, researchers also select respondents (parents and teachers) whose children or pupils in Year 4, 5 and 6 from four national primary schools (two urban and two rural) in Northern Zone of Peninsular Malaysia. The original sample saiz is 360 parents and 120 teachers. However, respondents who responded to the questionnaires are 302 (187 urban and 115 rural) parents and 104 (53 urban and 51 rural) teachers. The high response rate as 84 percent for parents and 87 percent for teachers respectively, considered as acceptable. The average age of Year 4 
pupils is 10 years old, Year 5 pupils is 11 years old and Year 6 pupils is 12 years old.

\section{Instrument}

The instruments used in this study are two sets of questionnaires (one set for the parents and the other set for the teachers). The researchers developed the questionnaires to measure parents' and teachers' views of primary school pupils' thinking skills and problem solving skills. Both instruments are based on de Bono's (1991) CoRT thinking tools such as PMI, CAF, RULES, C \& S, AGO, PLANNING, FIP, APC, DECISIONS and OPV and consist of 23 items each. A five-point Likert scale on a range of 1-5 was used for the questionnaires; with 5 points indicating very high, 4 points indicating high, 3 points indicating average, two points indicating low and 1 point indicating very low.

Besides that, the researchers also developed two sets of open-ended questions as a guide for the focus group interviews with parents and teachers. The purpose of the focus group interviews is to get feedback from parents and teachers on how to enhance pupils' thinking skills and problem solving skills.

\section{Validity of the Instruments}

Two experts in the area of thinking skills were asked to rate the questionnaires prepared by the researchers for parents and teachers using a 10 point scale $(1=$ very low to 10 = very high). A few changes were made to the questionnaires as suggested by the experts. After making the changes, the average rating score given by the experts was 10/10 for both the parents' and teachers' questionnaires. This is explained in Table $\mathbf{1}$.

Therefore, the results indicate that the questionnaires (to gauge parents' and teachers' views of pupils' thinking skills and problem solving skills) are valid and suitable for the study.

\section{Pilot Study}

Prior to the main study, a pilot study was carried out to obtain the reliability of the questionnaires used in this research. The pilot study was carried out over a period of two weeks in an urban primary school and a rural primary school. A total of 124 parents and 97 teachers were involved in the pilot study. The reliability of the questionnaires for parents and teachers was tested using the Reliability Coefficient Alpha. The findings as shown in Table 2 showed that the alpha values for both questionnaires are high and as such provide high internal reliability.

The semi-structured questions for the focus group interviews were also tested during the pilot test among parents and teachers, the researchers found that the items were sufficient to obtain information to answer the research questions.

Table 1.

Rating for the questionnaires.

\begin{tabular}{clccc}
\hline \multirow{2}{*}{ Expert } & \multicolumn{2}{c}{ Parent Instrument } & \multicolumn{2}{c}{ Teacher instruments } \\
\cline { 2 - 5 } & CV & LC & CV & LC \\
\hline Expert 1 & 10 & 10 & 10 & 10 \\
Expert 2 & 10 & 10 & 10 & 10 \\
Average & 10 & 10 & 10 & 10 \\
\hline
\end{tabular}

QA = Questionnaire; CV = Content validity; $\mathrm{LC}$ = Language and clarity.
Table 2.

Alpha value for the questionnaires.

\begin{tabular}{llc}
\hline Questionnaires & N & Alpha \\
\hline Parent Y4 & 42 & 0.93 \\
Parent Y5 & 30 & 0.91 \\
Parent Y6 & 52 & 0.94 \\
Teacher Y4 & 30 & 0.93 \\
Teacher Y5 & 34 & 0.92 \\
Teacher Y6 & 33 & 0.94 \\
\hline
\end{tabular}

\section{Research Procedure and Analysis}

The researchers had permission from the Ministry of Education Malaysia to conduct the study based on the requirements of the implementation procedures. After that, the researchers get the permission from the Education Department in the Northern Zone of Peninsular Malaysia, to carry out the research. The researchers also met the headmasters of the four schools to seek their readiness and permission in conducting the study. Subsequently the senior assistant in the schools helped the researchers to identify the teachers and the parents for the focus group interviews. Only parents and teachers of Year 4, 5 and 6 pupils are involved in the interviews. The criteria for choosing the interviewees are their willingness to participate in the interview. The interviews are recorded and transcribed by the researchers. The emerging themes from the parents and teachers interviews were used in the analysis of data.

This study employed both the quantitative and qualitative approaches. Parents' and teachers' views of pupils' thinking skills and problem solving skills were obtained through the questionnaire. Parents' and teachers' suggestions to enhance pupils' thinking skills and problem solving skills were derived through the focus group interviews.

The researchers distributed the questionnaires to the teachers in the staff room and briefed them on how to give the responses. The questionnaires for the parents were given to the pupils from the best classes in Year 4, 5 and 6 respectively. The researchers went through the questionnaire item by item with the pupils and requested them to give to their parents to obtain their parents' responses. The parents' and teachers' questionnaire were collected by the researchers and analyzed using the SPSS program version 18

\section{Findings and Discussion}

\section{Parents' Views of Children's Thinking Skills and Problem Solving Skills According to Location}

The findings as indicated from Table 3 showed that the urban parents' views of children's thinking skills and problem solving skills is higher than those from the rural. The mean

Table 3.

Parents' views of children's thinking skills and problem solving skills.

\begin{tabular}{ccccccc}
\hline Location & $\mathrm{N}$ & Mean & $\mathrm{SD}$ & $\mathrm{t}$ & $\mathrm{df}$ & $p$ \\
\hline Urban & 187 & 3.7291 & .48563 & & & \\
Rural & 115 & 3.4881 & .46771 & & & \\
\hline
\end{tabular}


score for the urban parents' is 3.7291 and the mean score for the rural parents is only 3.4881. The independent sample t-test indicated that the views of urban parents is significantly higher than the rural parents $(\mathrm{t}=4.247$, $\mathrm{df}=300, p=.000)$. Thus, finding reject Ho1 as no significant difference in the parents' views of children's thinking skills and problem solving skills according to location.

\section{Teachers' Views of Pupils' Thinking Skills and Problem Solving Skills According to Location}

Table 4 showed that there is no significant difference between the urban teachers and the rural teachers' views of pupils' thinking skills and problem solving skills $(\mathrm{t}=.423$, $\mathrm{df}=$ $102, p=.673$ ). The finding indicated that the mean score for urban teachers is slightly higher (mean $=3.2830$ ) than their rural counterparts (mean $=3.2464$ ). As such the finding fail to reject $\mathrm{Ho} 2$ as stated that there is no significant difference between the urban and rural teachers' views of pupils' thinking skills and problem solving skills.

\section{Parents' Suggestions to Enhance Children's Thinking Skills and Problem Solving Skills}

All the eight parents from the rural and urban schools agreed that thinking skills and problem solving skills are important for children in their daily lives.

Respondent 1 (Urban school 1): Thinking skills are important for children because they should be able to think about what is right and wrong and make the right decisions. We cannot always tell them what to do.

Some of the parents (50\%) from the rural area think that the children's levels of thinking skills and problem solving skills are weak and they need a lot of guidance from the teachers. Another $50 \%$ of the parents from the rural area think that their children's levels of thinking skills are at an average level. However, one parent from the urban school thinks that the child's levels of thinking skills and problem solving skills are high.

Respondent 1 (Urban school 1): My child is matured and has a high ability in thinking skills and problem solving skills. She is able to read newspapers fluently and can find information. She is able to take care of herself and solve problems when necessary.

Parents from both urban and rural schools gave various suggestions on how to enhance children's thinking skills and problem solving skills. Most of the parents think that parents should engage their children in thinking skills and problem solving activities while travelling, watching TV, taking dinner and before going to sleep. Parents' guidance over children is vital in helping them solve problems.

Respondent 2 (Rural school 2): I discuss with my son the various strategies of playing football, such as how to strike a goal. I also watch World Cup Football matches with my son and discuss with him the strategies used by the players during

Table 4.

Teachers' Views of Pupils’ Thinking Skills and Problem Solving Skills.

\begin{tabular}{ccccccc}
\hline Location & $\mathrm{N}$ & Mean & $\mathrm{SD}$ & $\mathrm{t}$ & $\mathrm{df}$ & $p$ \\
\hline Urban & 53 & 3.2830 & .36293 & .423 & 102 & .673 \\
Rural & 51 & 3.2464 & .51125 & & & \\
\hline
\end{tabular}

the matches. We also discuss the strength and the weaknesses of the players; as a football coach I also train my son and the school team at football.

Some parents think that giving children a balanced diet and supplements help them with their physical development and enhance their thinking skills and problem solving skills.

Respondent 2 (Rural school 2): As a father I also take good care of my son's food and physical development and always give him balanced meals and supplements to enhance his fitness and thinking skills. Drinks such as glucose can enhance children's energy and thinking skills. Foods such as raisins and fish protein help to enhance children thinking skills and problem solving skills.

Most parents engage their children in hands on activities at home, to enhance their thinking skills and problem solving skills, such as by training the children to keep the house clean, to take care of the garden, and to tie different types of knots.

Respondent 1 (Rural School 2): I teach my son how to tie a bundle using different types of knots; he is able to use this knowledge during his camping activities in school.

Respondent 1 (Rural School 1): I always encourage my child to find his own answers when doing his homework. I always teach him to be independent such as, by training him to wash his clothes, to tidy his room, to soak his shoes before washing them and to iron his clothes. I also teach him to water the plants, trim the plants and take care of the garden. I want him to be responsible and more independent.

Some parents engage their children in hands on activities such as bringing them along to the supermarket or wet market, allowing them to budget the marketing expenses and teaching them how to choose the items while shopping.

Respondent 1 (Urban School 2): I bring my son along when I go to the supermarket. I teach him how to choose the food items by checking the contents and the expiry dates. I also guide him to do the budget and not to spend lavishly.

Respondent 1 (Rural School 1): I bring my daughter to the wet market and train her on ways to choose fresh vegetables, such as choosing ladies fingers by testing if the tail ends break easily. The fish is fresh if it is not soft and the gills are red in colour. During the school holidays my daughter helps me to sell food at the night market.

Some parents commented that teachers are too busy and are not doing enough to develop their pupils' thinking skills and problem solving skills.

Respondent 1 (Urban School 2): Teachers should carry out "Project Based Learning" in schools. I think most teachers are not doing this because it involves a lot of work. Through "Project Based Learning", pupils really learn how to think and solve the problems.

\section{Teachers' Suggestions to Enhance Pupils' Thinking Skills and Problem Solving Skills}

All the eight teachers (four from rural schools and four from urban schools) think that their pupils' level of thinking skills and problem solving skills is only at the average level. However, teachers from the urban area commented that pupils from good classes have higher ability in thinking skills and problem solving skills compared to those from weaker classes.

Most of the teachers agreed that infusing thinking skills and problem solving skills is vital for pupils' meta-cognitive development. These skills are also important because at the end of 
Year six, pupils have to sit for the UPSR examination (National Year 6 Examination). There is $30 \%$ of the questions in this examination are at the lower level, $50 \%$ at the average level and $20 \%$ are at the higher level. Higher level questions require higher order thinking and pupils need thinking skills and problem solving skills to answer those questions. However, most teachers think that they are too busy in school and they find it difficult to infuse thinking skills and problem solving skills among weak pupils in the classroom.

Respondent 2 (Rural School 2): My pupils are too weak and I find it difficult to infuse thinking skills and problem solving skills during my lesson. I have to do a lot of "spoon feeding" and they need a lot of guidance from me.

Respondent 1 (Rural School 2): I think the implementation of thinking skills and problem solving skills is not effective among weak pupils but it is fruitful among good pupils.

Teachers from both the rural and urban areas propose various ways to enhance pupils thinking skills and problem solving skills. During the co-curriculum activities such as "living skills program" for scouts, teachers expose pupils to ways of cooking and being independent through hands on activities.

Respondent 1 (Urban School 1): They learn to cook; they have to think about how to boil rice, how to do the preparation to cook and how to serve the rice. They also learn how to survive in certain situations like when they are lost in the jungle.

Respondent 1 (Rural School 1): During camping activities, pupils learn how to put up a camp and how to tie the right knots. Pupils also learn to participate in treasure hunts. These activities help to enhance pupils' thinking skills and problem solving skills.

Respondent 2 (Urban School 1): Members of the Red Crescent Society are given the opportunity to act out an emergency situation, such as an accident or sustaining injuries and the members learn to help the victims in that particular situation. Through these activities, pupils are encouraged to think and solve problems.

Teachers also infuse thinking skills among pupils during the school assembly and activities such as dance drama. In some school assemblies, pupils are challenged with a thinking task, just to encourage them to think out of the box and to solve problems. Besides that, teachers engage pupils in problem solving skills by asking them to organize and present a dance drama.

Respondent 1 (Urban School 1): During every assembly we throw a thinking task to pupils and ask them to solve it. For example, we call out ten pupils to stand in front of the assembly and ask them to burst some balloons. Pupils from upper primary classes are also required to put up a show during the assembly, such as a dance drama. Before presenting the show pupils are encouraged to think and use their creativity for the presentation. Teachers allow them to make their own decision in choosing the characters, writing the dialog, preparing the costumes, and presenting it in a creative manner. The role of the teachers is only as a facilitator; the whole show is carried out by the pupils.

In the classroom some teachers employ various teaching strategies such as group work and pair work, to encourage pupils to use their thinking skills and problem solving skills. Teachers prepare worksheets for pupils according to their ability. Teachers also prepare checklists to record pupils' development from time to time. In short, teachers tailor their teaching strategies and teaching material to accommodate the diversity of the pupils in the classroom and actively monitor pupils' development and thinking skills.

Respondent 1 (Urban School 1): We teachers employ different teaching strategies according to the ability of the students. We prepared worksheets with high level challenging questions for the good classes and easier questions for the weak classes. We also encourage group work among the students and ask them to do group presentations. During group work pupils learn to generate ideas, solve problems and cooperate with group members.

Teachers also engage pupils in various competitions at school level, district level, and state level, such as the science quiz, mathematics quiz and cooking competition. While preparing for the competitions, pupils learn to solve their problems.

Respondent 2 (Rural School 2): Pupils in this school take part in various competitions at school level, district level and state level. They take part in the science quiz, mathematics quiz and cooking competition. Pupils need a lot of general knowledge and thinking skills in order to win the competition. Sometimes, in the science competitions, pupils are given a topic such as to design a spaceship. Pupils have to think creatively to design a spaceship; they also have to think of the materials to be used while modeling the spaceship. We won the competition in 2009 at the district level.

According to teachers, pupils' thinking skills and problem solving skills can be developed by taking them on excursions and visits, such as visiting factories, museums, historical places, forest reserves, and book exhibitions. During these visits, teachers prepare questions and pupils are required to find the answers. Such activities encourage pupils to be better thinkers, and learn to solve problems.

Respondent 1 (Rural School 1): Every semester we plan school educational trips for pupils and we take them to visit places such as factories, museums, historical places, forest reserves, and book exhibitions. At the factories, pupils learn how food stuff, such as biscuits, sweets and sardines are made. When visiting electronic factories pupils get ideas on how electronic parts are assembled in making hand phones, television sets, DVD players and radios.

Respondent 1 (Urban School 1): By visiting museums and historical places we can broaden pupils' knowledge and thinking skills. Pupils learn to appreciate the contribution of their forefathers in the development of the country.

Some teachers commented that parents are too ambitious and examination oriented; they only want their children to be book worms, attend tuition classes and score straight A's in their school subjects. They stop their children from watching TV totally. Pupils can get a lot of good ideas by watching good programs on TV such as "National Geographic" and the news broadcasts.

Respondent 1 (Urban School 1): Competition among parents is very high to the extent they only want their children to be book worms, attend many tuition classes and score straight A's in school subjects. They also stop their children from watching TV totally. There are a lot of good programs on TV which are suitable for children, such as National Geographic, Discovery Channel, Animal Planet and news. Parents should guide children while watching TV and teach them to adopt and adapt good ideas from the programs they watch.

\section{Conclusion}

The findings of this study revealed that the urban parents' 
views of children's thinking skills and problem solving skills is significantly higher than that of the rural parents. However, there is no significant difference in the teachers' views on that matter. Generally, teachers from urban and rural schools perceive their pupils' ability in thinking skills and problem solving skills to be at an average level. On the other hand, parents from urban schools perceive their children's ability in thinking skills and problem solving skills to be at a higher level. The parents from rural areas perceive children's thinking skills and problem solving skills to be at an average level.

The findings also revealed various methods employed by teachers and parents to enhance pupils' thinking skills and problem solving skills. The findings show that parents should engage their children in thinking skills and problem solving skills in their daily activities such as while traveling, watching TV, taking dinner and before going to sleep. Parents' guidance and motivation are important to enhance those skills among children.

Parents also must make sure that children are given balanced diet and supplements. Some parents think that it is beneficial to give their children balanced diets and supplements to enhance their thinking skills and problem solving skills. Parents should discuss with their children and encourage them to eat healthy food such as fruits and salads (Cheney, Favell, Harrison, Hurst, \& Yates; 2010) because healthy foods are important for children's cognitive development. Besides that, parents should also engage their children on hands on activities such as training the children to do household chores, shopping at the supermarket, doing marketing at the wet market, doing the budget and helping parents in their business. Such training enrich children's experiences in solving problems and make them more competent at their thinking skills and problem solving skills.

Some teachers commented that some parents are too examination oriented to the extent that they only think of giving tuition to their children and drive them to get straight A's. They even stop their children from watching TV and only want them to be book worms. These parents should help and guide their children to be balanced individuals. Parents should also allow their children to watch good TV programs and discuss the positive and negative aspects of the program to enhance their thinking skills.

With regards to teachers' suggestions at enhancing pupils thinking skills and problem solving skills, some teachers commented that they are too busy and find it difficult to infuse thinking skills and problem solving skills in their classroom lessons. It is important for the teachers to be competent at various skills to help pupils in their thinking skills and problem solving skills. The ministry of education should conduct courses for the in service teachers on ways to infuse thinking skills among pupils of different abilities. This is important, so that teachers do not neglect the weaker pupils and only concentrate on the good ones while teaching. The finding from the focus group interviews also show that teachers should use different kinds of material to accommodate the diversity of the pupils, such as using different worksheets for pupils of different levels.

Teachers should encourage active participation of pupils in co-curricular activities, such as camping, competitions and learning to give first aid. These activities give a lot of space for pupils to enhance their thinking skills and problem solving skills.

Another integral part of developing thinking skills and problem solving skills is by organizing educational trips for pupils such as visits to museums, historical places, factories and holiday resorts. Teachers should organize such visits to broaden pupils' knowledge and thinking skills. Teachers should always encourage and motivate pupils to think in creative ways and solve problems.

Some parents mentioned that some teachers are not doing enough to promote thinking skills and problem solving skills among pupils. They think that teachers should be more committed to enhancing pupils' thinking skills and problem solving skills. One of the ways is by engaging pupils in "Project Based Learning" in schools. Through "Project Based Learning" pupils learn a lot of things such as being independent, sharing, learning to think and solving their own problems. It is hoped that the findings of this study will give some insight to parents, teachers and the ministry of education on how to enhance pupils' thinking skills and problem solving skills.

This study was conducted among parents and teachers from four primary schools in the state of Kedah situated in the Northern Zone of Malaysia. I would like to suggest future research to be carried out among parents and teachers from more primary schools in Malaysia. Similar research can also be carried out among parents and teachers in the secondary schools. This research did not involve pupils in the focus group interview; it is hoped that future research will include pupils in the focus group interview so that we can get more information from the pupils on the activities carried out by teachers in the classrooms and suggestions from pupils to enhance their thinking skills and problem solving skills.

This case study highlighted that parents and teachers play an important role in developing pupils' thinking skills and problem solving skills. However, most of the teachers are having problems to infuse thinking skills and problem solving skills among weak pupils because of the time constraint. Consequently, certain amount of time to practice thinking skills and problem solving skills through activities should be included in classroom teaching. Creative education not only isolated to good pupils but also to weak pupils as well. Developing creative thinking among the pupils is all depending on the creativity of their teacher in guiding the pupils to generate new and noble ideas, and various ways of solving problems.

\section{REFERENCES}

Ambreen, A. (2009). Teacher's role in improving students' thinking skills: Moving beyond the "sage on the stage". Teachers.net Gazette. URL (last checked 28 March 2009). http://www.teachers.net/gazette

Amabile, T. M. (1983). The social psychology of creativity: A componential conceptualization. Journal of Personality and Social Psychology, 43, 997-1013. doi:10.1037/0022-3514.43.5.997

Barret, T. C. (1972). Taxonomy of reading 360 monograph. Lexington, Mass: Ginn A Xerox Education Company.

Beyer, B. K. (1987). Practical strategies for the teaching of thinking. Boston, MA: Allyn and Bacon.

Beyer, B. K. (1991). Teaching thinking skills: A hand book for secondary school teachers. Boston, MA: Allyn and Bacon.

Bloom, B. S. (1956). Taxonomy of educational objectives. Handbook 1, Cognitive Domain. New York: Longman, Green and Company.

Buzan, T. (1986). Use of memory. London: BBC Publications.

Campbell, L. Campbell, B. \& Dickinson, D. (1996). Teaching and learning through multiple intelligence. London: Allyn and Bacon.

Cheney, A., Favell, H., Harrison, C., Hurst, G., \& Yates, C. (2010). Thinking through science 2: Teacher's Book. URL (last checked 7 December 2010). 
http://www.hoddersanplepages.co.uk/pdfs/tts2TchBk.pdf

Clarke, J. H. (1990). Patterns of thinking. Boston, MA: Allyn and Bacon.

De Bono, E. (1991). The direct teaching of thinking in education and the CoRT method. In Maclure, S. (Ed.), Learning to think thinking to learn (pp. 3-14). Oxford: Pergamom Press

Dewey, J. (1938). How we think. Revised and expanded edition with Foreword by Maxine Greene. Houghton: Mifflin.

Duke Gifted Letter. (2006). Enhancing critical-thinking skills in children: Tips for parents. URL (last checked 28 March 2011).

http://www.dukegiftedletter.com

English One Stop Centre. (2001). English syllabus for KBSR (integrated curriculum for Malaysian Primary School). URL (last checked 25 September 2010). http://ranitaawang.net/page.php?25

Gardner, H. (1984). Frames of mind: Theory of multiple intelligences. New York, NY: Basic Book Inc.

Guilford, J. P. (1967). The nature of human intelligence. New York, NY: Mc Graw-Hill.

Meyers, C. (1986). Teaching students to think critically. San Francisco, CA: Jossey-Bass Publishers, 1-10.

Mumford, M. D. (2001). Something old, something new: Revising Guilford's conception of creative problem solving. Creativity Research Journal, 13, 267-276. doi:10.1207/S15326934CRJ1334_04

Mumford, M. D., Mobley, M. I., Uhlman, C. E., Reiter-Palmon, R., \&
Doares, L. M. (1991). Process analytic models of creative capacities. Creativity Research Journal, 4, 91-122. doi:10.1080/10400419109534380

Novak, J. D., \& Gowin, D. B. (1984). Learning how to learn. New York, NY: Cambridge University Press.

Schafersman S. D. (1991). An introduction to critical thinking. URL (last checked 28 March 2011).

http://www.freeinquiry.com/critical-thinking.html

Smith, N. B. (1969). The many faces of reading comprehension. The Reading Teacher, 23, 246-260.

Spache, G. D. (1978). Psychological and cultural factors in learning to read. In: D. Lapp, \& J. Flood, (1975). Teaching reading to every child (p. 7). New York: Mcmillan Publishing Company, Inc.

Sternberg, R. J. (1988). The nature of creativity: Contemporary psychological perspectives. New York: Cambridge University Press.

Swartz, R. J., \& Parks, S. (1994). Infusing critical and creative thinking into content instruction. Massachusetts: Critical Thinking Press \& Software.

The Learning Community. (2011). Tips for parents: Parent involvement. URL (last checked 28 March 2011). http://www.thelearningcommunity.us

Tillery, B. W. (2006) Problem solving techniques. URL (last checked 5 November 2006).

http://www.dushkin.com/online/study/problemsolving.mhtml 